\title{
Antibiotic Resistance and Pathogenomics of Staphylococci Circulating in Novosibirsk, Russia
}

\author{
Alevtina Bardasheva ${ }^{1}$, Artem Tikunov ${ }^{1}$, Yuliya Kozlova ${ }^{1}$, Elena Zhirakovskaia ${ }^{1}{ }^{\circledR}$, Valeriya Fedorets ${ }^{1}$, \\ Natalya Fomenko ${ }^{2}$, Tatyana Kalymbetova ${ }^{2}$, Svetlana Chretien ${ }^{3}$, Vitaliy Pavlov ${ }^{3}$, Nina Tikunova ${ }^{1, *}$ \\ and Vera Morozova ${ }^{1, *}$ \\ 1 Institute of Chemical Biology and Fundamental Medicine SB RAS, Lavrentiev Avenue 8, \\ 630090 Novosibirsk, Russia; herba12@mail.ru (A.B.); arttik@ngs.ru (A.T.); ulona@ngs.ru (Y.K.); \\ ezhr@niboch.nsc.ru (E.Z.); f.valeriya41@gmail.com (V.F.) \\ 2 Joint-Stock Company Vector-Best, P.O. Box 121, 630117 Novosibirsk, Russia; FomenkoN@vector-best.ru (N.F.); \\ Kalymbetova@vector-best.ru (T.K.) \\ 3 Novosibirsk Research Institute of Traumatology and Orthopedics n.a. Ya. L. Tsivyan, Frunze 17, \\ 630091 Novosibirsk, Russia; ssonovo@inbox.ru (S.C.); pavlovdoc@mail.ru (V.P.) \\ * Correspondence: tikunova@niboch.nsc.ru (N.T.); morozova@niboch.nsc.ru (V.M.)
}

Citation: Bardasheva, A.; Tikunov, A. Kozlova, Y.; Zhirakovskaia, E.; Fedorets, V.; Fomenko, N.;

Kalymbetova, T.; Chretien, S.; Pavlov,

V.; Tikunova, N.; et al. Antibiotic

Resistance and Pathogenomics of Staphylococci Circulating in Novosibirsk, Russia. Microorganisms 2021, 9, 2487. https://doi.org/ 10.3390/microorganisms 9122487

Academic Editors: Edward R. B. Moore and Daniel Jaén Luchoro

Received: 6 November 2021

Accepted: 29 November 2021

Published: 30 November 2021

Publisher's Note: MDPI stays neutral with regard to jurisdictional claims in published maps and institutional affiliations.

Copyright: (c) 2021 by the authors. Licensee MDPI, Basel, Switzerland. This article is an open access article distributed under the terms and conditions of the Creative Commons Attribution (CC BY) license (https:// creativecommons.org/licenses/by/ $4.0 /)$.

\begin{abstract}
A total of 394 strains of staphylococci found in humans and pets in Novosibirsk, Siberian Russia, were characterized in terms of antibiotic resistance and corresponding genes. Two coagulasepositive and 17 coagulase-negative species were identified. The majority of isolates, with the exception of S. haemolyticus and hospital S. epidermidis isolates, were sensitive to most of the tested antibiotics, and isolates from pets displayed the lowest level of resistance. Nevertheless, methicillinresistant (MRS) and/or multidrug-resistant (MDR) isolates were found in all prevailed species, including coagulase-negative. A set of genes corresponding to the detected resistance was identified:

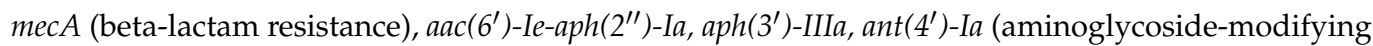
enzymes), ermA/erm $C$, and $m s r A$ (macrolide resistance). Complete genome analysis for ten MDR S. epidermidis and five MDR $S$. haemolyticus isolates revealed additional antibiotic resistance genes $m p h C, q a c A / q a c B$, nor $A, d f r C / d f r G, \ln u A, B s e S R$, and fos $B$. Nor $A, d f r C$, and fos $B$ were present in all $S$. epidermidis genomes, whereas $m p h C$ and $m s r A$ were identified in all S. haemolyticus ones. All investigated MDR S. epidermidis and four of five $S$. haemolyticus strains were moderate or strong biofilm producers, whereas multiple genes responsible for this function and for virulence and pathogenicity were identified mostly in S. epidermidis, but were less frequently represented in S. haemolyticus.
\end{abstract}

Keywords: Staphylococcus; coagulase-negative staphylococci; MDR; MRS; ST; pathogenomics; virulence factors; antibiotic resistance genes; Siberia; Russia

\section{Introduction}

Staphylococci are Gram-positive facultative anaerobic bacteria that belong to the Staphylococcaceae family and Staphylococcus genus. To date, approximately 60 validated members of the genus have been described (https:/ / lpsn.dsmz.de/genus/staphylococcus, accessed on 10 September 2021). Most bacteria from this genus normally inhabit the skin and mucosae of humans and animals and are also a part of soil microbial communities. At the same time, staphylococci can affect almost any organs and tissues of the human body, causing superficial and deep purulent abscesses, respiratory and urinary tract infections, purulent-necrotic processes in postoperative wounds, and food poisoning or intoxication [1].

Staphylococci are divided into coagulase-positive (able to produce coagulase) and coagulase-negative species. Among coagulase-positive species, Staphylococcus aureus is the most clinically important. A number of other coagulase-positive staphylococci (Staphylococcus delphini, Staphylococcus intermedius, and Staphylococcus pseudintermedius, belonging to the 
Staphylococcus intermedius group) are causative agents of the most common staphylococcal infections in veterinary medicine and can also be transmitted to humans through close contact with animals [2-4]. Coagulase-negative members of the genus are considered less virulent and are usually identified as commensals [1]. Nevertheless, cases of infections have become more frequent in people, the causative agents of which are coagulase-negative species Staphylococcus epidermidis, Staphylococcus saprophyticus, Staphylococcus haemolyticus, and Staphylococcus hominis [5]. The most common and studied of the coagulase-negative staphylococci is S. epidermidis, which is normally a commensal of the skin and mucous surfaces. However, the ability of $S$. epidermidis to form biofilms makes it a serious problem in surgery associated with implanted structures [6].

Notably, S. epidermidis and other coagulase-negative staphylococci are an important reservoir of antibiotic resistance genes. Diseases caused by methicillin-resistant staphylococci (MRS) that are resistant to beta-lactams are particularly difficult to treat, especially when methicillin resistance is associated with reduced sensitivity to antibiotics from other classes. For many years, coagulase-negative MRS strains were considered exclusively as hospital pathogens; however, the situation has changed for the worse as these pathogens are increasingly causing community-acquired infections [7,8]. It has been shown that staphylococci with multiple drug resistances (MDR) can be present in wastewater and in other places associated with human activity $[9,10]$.

Most studies of staphylococci in Russia focused on the monitoring of antibiotic resistant isolates in hospitals and were often limited to characterizing only S. aureus [11-15]. Only a few studies of environmental, veterinary, and community-associated staphylococci in Russia have been published [16,17]. Data on genomes, virulence factors (VF), and antibiotic resistance genes (ARG) of staphylococci found in Russia are still limited, especially in Siberian Russia, which is located between the Far Eastern and European regions. A few S. aureus complete genome studies have been published [17-19]. No data regarding the genome characteristics of coagulase-negative staphylococci from Russia have been reported.

In this study, staphylococci found in humans and pets in Novosibirsk, Siberian Russia, were characterized in terms of antibiotic resistance and respective ARGs. In addition, five MDR S. haemolyticus and ten S. epidermidis isolates were examined for the ability to form biofilms. Their complete genomes were sequenced and analyzed, focusing on the genes responsible for pathogenicity factors and biofilm formation.

\section{Materials and Methods}

\subsection{Bacterial Strain Isolation and Identification}

Clinical specimens and pure cultures were obtained from a number of Novosibirsk hospitals and medical centers, including Railway Clinical Hospital, Department of Surgery of Purulent Wounds; Novosibirsk Research Institute of Traumatology and Orthopedics, Department of Endoscopic Joint Surgery; Scientific Institute of Clinical and Experimental Lymphology, Department of Diabetic Foot Therapy; Center of New Medical Technologies, Department of Gynecology; City Infectious Diseases Clinical Hospital No. 1, Department of Gastroenterology; and the Federal Center of Neurosurgery. The specimens included biopsy material, wound exudate, synovial liquid, cerebrospinal fluid, swabs, urine and fecal samples, skin and mucosal scrapings, sputum, and pure bacterial cultures; the last was obtained from the hospitals. Veterinary isolates were obtained from specimens taken from pets (cats and dogs) in veterinary clinics of Novosibirsk. The origin and amount of clinical and veterinary isolates are listed in Table 1 . Ten-fold dilutions of specimens were prepared and the resulting cell suspensions were plated on mannitol salt agar (OXOID, Basingstoke, UK). Cells were grown at $35^{\circ} \mathrm{C}$ in an aerobic atmosphere for $18-24 \mathrm{~h}$, and individual colonies were passaged three times under the same conditions. Pure bacterial cultures were obtained, and bacteria of the genus Staphylococcus were determined by cultural and morphological characteristics. In each of the specimens, from one to three isolates were obtained, differing in colony morphology, growth rate, and biochemical properties. Pure 
cultures of staphylococci were deposited in the Collection of Extremophilic Microorganisms and Type Cultures of the Institute of Chemical Biology and Fundamental Medicine Siberian Branch of Russian Academy of Science (CEMTC ICBFM SB RAS).

Table 1. The origin of Staphylococcus isolates.

\begin{tabular}{ccc}
\hline Panels & Origin of Strains & Number of Isolates \\
\hline & Prosthetic joint and post-operative & 56 \\
Strains isolated from & wound infections & 43 \\
hospitalized patients $(n=105)$ & Purulent diabetic ulcers & 3 \\
& Decubitus ulcers & 2 \\
& Sputum from a patient with pneumonia & 1 \\
\hline & Cerebrospinal fluid & 83 \\
Strains from outpatients & Respiratory tract infections & 59 \\
$(n=228)$ & Skin and mucosal infections & 21 \\
& Urinary tract infections & 25 \\
& Bacterial vaginosis & 36 \\
\hline Strains from pets $(39$ from dogs & Fecal samples from patients & 4 \\
and 22 from cats) $(n=61)$ & with diarrhea & 57 \\
\hline
\end{tabular}

Strains, conserved at $-80{ }^{\circ} \mathrm{C}$ in a lysogeny broth medium (LB) containing $25 \%$ glycerol, were subcultured in LB medium and on LB agar plates. All cultures were grown at $37^{\circ} \mathrm{C}$ for $48 \mathrm{~h}$, and the colonies grown were used for PCR amplification of the 16S rRNA gene. Subsequent identification of the strains was performed by sequencing the 1308-bp PCR fragment of the 16S rRNA gene, as described previously [20]. All PCR amplicons were gel purified $\left(0.6 \%\right.$ SeaKem ${ }^{\circledR}$ GTG-agarose, Lonza, ME, USA) and sequenced (BigDye ${ }^{\mathrm{TM}}$ Terminator v.3.1 Cycle Sequencing Kit and ABI 3500 Genetic Analyzer, Applied Biosystems, Foster City, CA, USA). The obtained nucleotide sequences of $16 \mathrm{~S}$ rRNA genes were compared with the corresponding nucleotide sequences extracted from the NCBI GenBank database (http: / / www.ncbi.nlm.nih.gov, accessed on 1 April 2021). The closest reference sequences of the genus Staphylococcus were used with a sequence similarity level of at least $98 \%$, and species names were determined according to a recently published updated classification [21]. Additional identification was done for a number of isolates using GEN III OmniLog Plus ID System (Biolog, Inc., Hayward, CA, USA).

All patient data were collected anonymously. Isolates were considered as hospital specimens if they were obtained from patients who had been in the clinic for at least two weeks and were treated with antibiotics during that time. The isolates were considered as outpatient if they were obtained from patients who were not hospitalized or from patients who had been hospitalized only a few hours. The study was approved by a local ethics Committee of the Center for New Medical Technologies in Novosibirsk; protocol \#2, 12 February 2014.

\subsection{Susceptibility Testing}

Susceptibility to five antibiotics was determined using a disk diffusion test according to the guidelines of EUCAST 10.0 (https:/ / eucast.org, accessed on 10 September 2020). Cefoxitin (FOX, $30 \mu \mathrm{g}$ ), amikacin (AMK, $30 \mu \mathrm{g})$, gentamicin (CN, $10 \mu \mathrm{g})$, erythromycin $(\mathrm{E}, 15 \mu \mathrm{g})$, and clindamycin (DA, $2 \mu \mathrm{g}$ ) were examined. Disks with antibiotics (OXOID) were applied to the lawns of the investigated cultures on Mueller-Hinton agar (OXOID). Cefoxitin was used as a marker for the detection of methicillin resistance and strain S. aureus ATCC 25923 was used as a control of susceptibility. 


\subsection{Antibiotic Resistance Genes Detection}

Bacterial DNA was extracted from bacterial cultures grown at $35{ }^{\circ} \mathrm{C}$ overnight in $2 \mathrm{~mL}$ of brain heart infusion broth (BHI Broth, BioMerieux, Marcy-l'Étoile, France) using a DNA extraction kit (Biolabmix, Novosibirsk, Russia) according to the manufacturer's instructions. Subsequently, all strains were tested for the presence of genes that contribute to the resistance to various classes of antibiotics: mec $A$ and blaZ genes (beta-lactam and

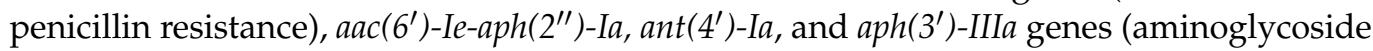
resistance), and erm $A$, erm $C$, and $m s r A$ genes (macrolide and lincosamide resistance) using a set of primers (Table S1).

\subsection{Study of Biofilm Formation}

The study of staphylococcus biofilm formation with the crystal violet staining method was done as described previously [22]. Briefly, an overnight growth culture in tryptic soy broth (TSB) medium (Merch, Darmstadt, Germany) was adjusted to a final $\mathrm{OD}_{600}$ of $1.00 \pm 0.05$ by adding sterile TSB. This OD-adjusted suspension was then diluted 100-fold with TSB containing $1 \%$ glucose to obtain the initial bacterial suspension. The wells of a 96-well microplate (TPP, Trasadingen, Switzerland) were inoculated with $200 \mu \mathrm{L}$ of the suspension and incubated at $35^{\circ} \mathrm{C}$ for $24 \mathrm{~h}$. A control well was inoculated with a sterile TSB medium containing $1 \%$ of glucose. Each experiment was done in triplicate in three technical repeats. The medium was removed and the wells were washed three times with sterile saline solution. The wells were air dried for $45 \mathrm{~min}$, and the adherent cells were stained with a $0.1 \%$ water solution of crystal violet at room temperature for $30 \mathrm{~min}$. Next, the excess crystal violet was removed and the wells were washed five times with $300 \mu \mathrm{L}$ sterile saline solution. The dye was dissolved with $150 \mu \mathrm{L}$ of $96 \%$ ethanol and the absorbance of each well was read at $595 \mathrm{~nm}$ in a microplate reader (Uniplan, Moscow, Russia). The results were processed and interpreted as described previously [22]. In brief, the average OD values $\left(\mathrm{OD}_{\mathrm{av}}\right)$ were calculated for all tested strains and for a negative control (non-inoculated medium). The cutoff value $\left(\mathrm{OD}_{\mathrm{c}}\right)$ was defined as three standard deviations above the mean $\mathrm{OD}$ of the negative control $\left(\mathrm{OD}_{\mathrm{c}}=\mathrm{OD}_{\mathrm{av}-\mathrm{neg}}+3 \times \mathrm{SD}\right)$. The strains were divided into three categories, based on the calculated $\mathrm{OD}_{\mathrm{c}}$ : $\mathrm{OD}_{\mathrm{c}}<\mathrm{OD}_{\mathrm{av}} \leq 2 \times \mathrm{OD}_{\mathrm{c}}$ was defined as a weak biofilm producer; $2 \times \mathrm{OD}_{\mathrm{c}}<\mathrm{OD}_{\mathrm{av}} \leq 4 \times \mathrm{OD}_{\mathrm{c}}$ was defined as a moderate biofilm producer; $4 \mathrm{OD}_{\mathrm{c}} \leq \mathrm{OD}_{\mathrm{av}}$ was defined as a strong biofilm producer.

\subsection{Complete Genome Sequencing and Analysis}

Bacterial DNA was extracted from bacterial cultures grown at $35^{\circ} \mathrm{C}$ overnight in $10 \mathrm{~mL}$ of brain heart infusion broth (BioMerieux, Marcy-l'Étoile, France) using a DNA extraction kit (Biolabmix, Novosibirsk, Russia) according to the manufacturer's instructions.

The extracted DNA was further used for a paired-end library construction, which was performed using a NEB Next DNA Ultra library prep kit (New England Biolabs, Ipswich, MA, USA). Sequencing was carried out using a MiSeq Benchtop Sequencer (Illumina, Inc., San Diego, CA, USA) and a MiSeq Reagent Kit $2 \times 250$ v. 2.0 (Illumina, San Diego, CA, USA). The obtained sequences were assembled de novo using the SPAdes genome assembler v.3.15.2 (http:/ / cab.spbu.ru/software/spades, accessed on 1 August 2021). Annotation was performed using Rapid Annotation Subsystem Technology (RAST) v.2.0 (https:/ / rast.nmpdr.org, accessed on 2 September 2021). The genomes and their RAST annotations are located in Supplementary Data S1 and S2, respectively. The obtained sequences were analyzed for the presence of antibiotic resistance genes (ARG) and virulence factors (VF) using a Resistance Genes Identifier (https: / / card.mcmaster.ca/analyze/rgi, accessed on 2 September 2021) and the Virulence Factor Database (http:/ / www.mgc.ac.cn/ VFs, (accessed on 3 September 2021), respectively. In addition, the genomes were checked for the presence of ARGs and VFs manually, using RAST annotation and BLAST search. The sequence types for MDR Staphylococcus strains were determined using the PubMLST database (https: / / pubmlst.org, accessed on 15 September 2021), and the clonal complexes were identified using a BURST analysis [23]. 
All Staphylococcus sequences/genomes are publicly available through NSBI resources under BioProject PRJNA774949. Unassembled sequencing reads have been deposited in the NCBI Short Read Archive (SRA) under accessions SRR16591584-SRR16591598. Whole Genome Shotgun projects have been deposited at DDBJ/ENA/GenBank under accessions JAJFNL000000000, JAJFNM000000000, JAJFNN000000000, JAJFNO0000000000, JAJFNP000000000, JAJFNQ000000000, JAJFNR000000000, JAJFNS000000000, JAJFNT000000000, JAJFNU000000000, JAJFNV000000000, JAJFNW000000000, JAJFNX000000000, JAJFNY000000000, and JAJFNZ000000000. Versions described in this paper are JAJFNL010000000, JAJFNM010000000, JAJFNN010000000, JAJFNO010000000, JAJFNP010000000, JAJFNQ010000000, JAJFNR010000000, JAJFNS010000000, JAJFNT010000000, JAJFNU010000000, JAJFNV010000000, JAJFNW010000000, JAJFNX010000000, JAJFNY010000000, and JAJFNZ010000000.

\section{Results}

\subsection{Staphylococcus Strain Isolation and Identification}

In 2014-2020, a collection of 394 strains of staphylococci from humans and pets (dogs and cats) was isolated in Novosibirsk, Russia (Table 1). Nineteen Staphylococcus species were revealed (Table 2), and five strains were identified as belonging to the newly established Mammaliicoccus genus [21].

Table 2. Species identification of clinical and veterinary staphylococci isolates.

\begin{tabular}{|c|c|c|c|}
\hline No & Species (Number of Isolates) & $\begin{array}{c}\text { Isolation Source } \\
\text { (Number of Isolates) }\end{array}$ & GenBank Identifier for 16S rRNA Gene \\
\hline \multirow{3}{*}{1} & \multirow{3}{*}{ Staphylococcus aureus (167) } & Hospital (74) & No ID \\
\hline & & Outpatient (81) & No ID \\
\hline & & Veterinary (12) & No ID \\
\hline 2 & Staphylococcus auricularis (4) & Outpatient (4) & MZ014399-MZ014402 \\
\hline 3 & Staphylococcus borealis (2) & Outpatient (2) & MZ014403, MZ014404 \\
\hline 4 & Staphylococcus capitis (4) & Outpatient (4) & MZ014405-MZ014407, MZ014411 \\
\hline \multirow{2}{*}{5} & \multirow{2}{*}{ Staphylococcus caprae (5) } & Hospital (1) & MZ014409 \\
\hline & & Outpatient (4) & MZ014408, MZ014410, MZ014412, MZ014413 \\
\hline 6 & Staphylococcus carnosus (2) & Outpatient (2) & MZ014414, MZ014415 \\
\hline 7 & Staphylococcus casei (2) & Outpatient (1) & MZ014416 \\
\hline 8 & $\begin{array}{c}\text { Staphylococcus coagulans/S. schleiferi subsp. } \\
\text { coagulans (8) }\end{array}$ & Veterinary (8) & MW979964-MW979970 \\
\hline 9 & Staphylococcus cohnii (2) & Outpatient (2) & MZ014417, MZ014418 \\
\hline 10 & Staphylococcus devriesei (4) & Outpatient (4) & MZ014419-MZ014422 \\
\hline \multirow{2}{*}{11} & \multirow{2}{*}{ Staphylococcus equorum (3) } & Outpatient (1) & MZ014423 \\
\hline & & Veterinary (2) & MW979955, MW979971 \\
\hline \multirow{4}{*}{12} & \multirow{4}{*}{ Staphylococcus epidermidis (104) } & Hospital (20) & $\begin{array}{c}\text { MZ027385-MZ027397, MZ040881, MZ040882, } \\
\text { MZ041685 }\end{array}$ \\
\hline & & & MZ027349-MZ027358, MZ027360-MZ027362, \\
\hline & & Outpatient (84) & $\begin{array}{c}\text { MZ027364-MZ027366, MZ040893-MZ040916, } \\
\text { MZ047203-MZ047210, }\end{array}$ \\
\hline & & & MZ049531-MZ049537,MZ723062 \\
\hline 13 & Staphylococcus felis (5) & Veterinary (5) & MW979972-MW979976 \\
\hline \multirow{3}{*}{14} & \multirow{3}{*}{ Staphylococcus haemolyticus (22) } & Hospital (2) & MZ027398, MZ027399 \\
\hline & & Outpatient (19) & MZ027367-MZ027375, MZ040917-MZ040921, \\
\hline & & Veterinary (1) & $\begin{array}{c}\text { MZ047213-MZ047216, MZ723059, MZ723059 } \\
\text { MW979956 }\end{array}$ \\
\hline
\end{tabular}


Table 2. Cont.

\begin{tabular}{|c|c|c|c|}
\hline No & Species (Number of Isolates) & $\begin{array}{c}\text { Isolation Source } \\
\text { (Number of Isolates) }\end{array}$ & GenBank Identifier for 16S rRNA Gene \\
\hline 15 & Staphylococcus hominis (14) & $\begin{array}{l}\text { Hospital (2) } \\
\text { Outpatient (11) } \\
\text { Veterinary (1) }\end{array}$ & $\begin{array}{l}\text { MZ014434, MZ014435 } \\
\text { MZ014424-MZ014433 } \\
\text { MW979977 }\end{array}$ \\
\hline 16 & Staphylococcus pasteuri (1) & Outpatient (1) & MZ047217 \\
\hline 17 & Staphylococcus pseudintermedius (24) & Veterinary (24) & $\begin{array}{c}\text { MW965646, MW979953, } \\
\text { MW979978-MW979995, MW979997, } \\
\text { MW979998 }\end{array}$ \\
\hline 18 & Staphylococcus simulans (8) & $\begin{array}{l}\text { Hospital (1) } \\
\text { Outpatient (5) } \\
\text { Veterinary (2) }\end{array}$ & $\begin{array}{c}\text { MZ014437 } \\
\text { MZ014436, MZ014438-MZ014441 } \\
\text { MW979999, MW980000 }\end{array}$ \\
\hline 19 & Staphylococcus warneri (8) & $\begin{array}{l}\text { Hospital (2) } \\
\text { Outpatient (5) } \\
\text { Veterinary (1) }\end{array}$ & $\begin{array}{c}\text { MZ014445, MZ014447 } \\
\text { MZ014442-MZ014444, MZ014446, MZ014448 } \\
\text { MW979957 }\end{array}$ \\
\hline 20 & $\begin{array}{c}\text { Mammaliicoccus sciuri/ Staphylococcus } \\
\text { sciuri (3) }\end{array}$ & $\begin{array}{l}\text { Hospital (1) } \\
\text { Veterinary (2) }\end{array}$ & $\begin{array}{c}\text { MW965541 } \\
\text { MW965545, MW965551 }\end{array}$ \\
\hline 21 & $\begin{array}{c}\text { Mammaliicoccus vitulinus / Staphylococcus } \\
\text { vitulinus (1) }{ }^{1}\end{array}$ & Veterinary (1) & MW965552 \\
\hline 22 & $\begin{array}{c}\text { Mammaliicoccus lentus / Staphylococcus } \\
\text { lentus (1) }\end{array}$ & Veterinary (1) & MW965543 \\
\hline
\end{tabular}

${ }^{1}$ The species were moved to the newly established Mammaliicoccus genus [21], previous species names are separated by slash.

S. aureus, S. epidermidis, S. haemolyticus, and S. hominis were the major species in clinical samples, whereas $S$. pseudintermedius was the dominant species in veterinary samples. The distribution of coagulase-positive and coagulase-negative staphylococci varied in different panels (Figure 1). Among the strains obtained from hospitalized patients, S. aureus strains prevailed $(\sim 70 \%)$; the share of $S$. epidermidis strains was approximately $19 \%$, and S. haemolyticus, S. warneri, and other staphylococci accounted for $11 \%$. Outpatient isolates had a different ratio of species: S. aureus, S. epidermidis, and S. haemolyticus were at approximately $35 \%, 37 \%$, and $9 \%$, respectively. Veterinary isolates contained $\sim 39 \%, 20 \%$, and $13 \%$ of the S. pseudintermedius, S. aureus, and $S$ coagulans strains, respectively (Figure 1, Table 2). The 16S rRNA gene sequences of all investigated Staphylococcus strains (except S. aureus strains) were deposited in the NCBI GenBank database. A list of the accession numbers for 16S rRNA gene sequences is given in Table 2.

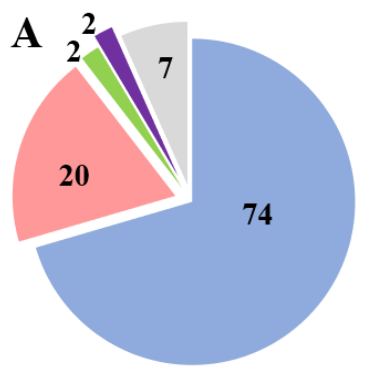

$N=105$

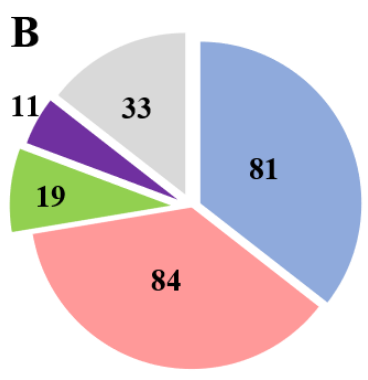

$N=\mathbf{2 2 8}$

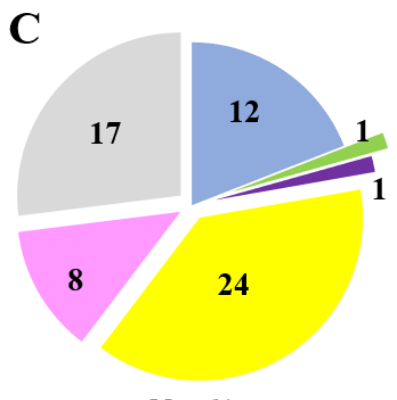

$N=61$

Figure 1. Species distribution of staphylococci isolates from hospitalized patients (A), outpatients (B), and pets (C). Colors: blue-S. aureus, light red-S. epidermidis, green-S. haemolyticus, violetS. hominis, yellow-S. pseudintermedius, pink—S.coagulans, grey-other staphylococci species. The number of isolates for each species is represented in the circle segments. 


\subsection{Antibiotic Resistance and Resistance-Encoding Genes}

All Staphylococcus isolates were tested for antibiotic resistance (Figure 2). The majority of them $(\sim 85 \%, 330 / 389)$ were methicillin-sensitive (MSS), including $91 \%$ of $S$. aureus, $70 \%$ of S. epidermidis, $85 \%$ of $S$. hominis, and all isolates from other species. The exception was S. haemolyticus isolates: $\sim 60 \%(13 / 22)$ of them were MRS.

S. aureus S.epiderm. S.haemol. S.hominis S.pseudi. ${ }^{1}$

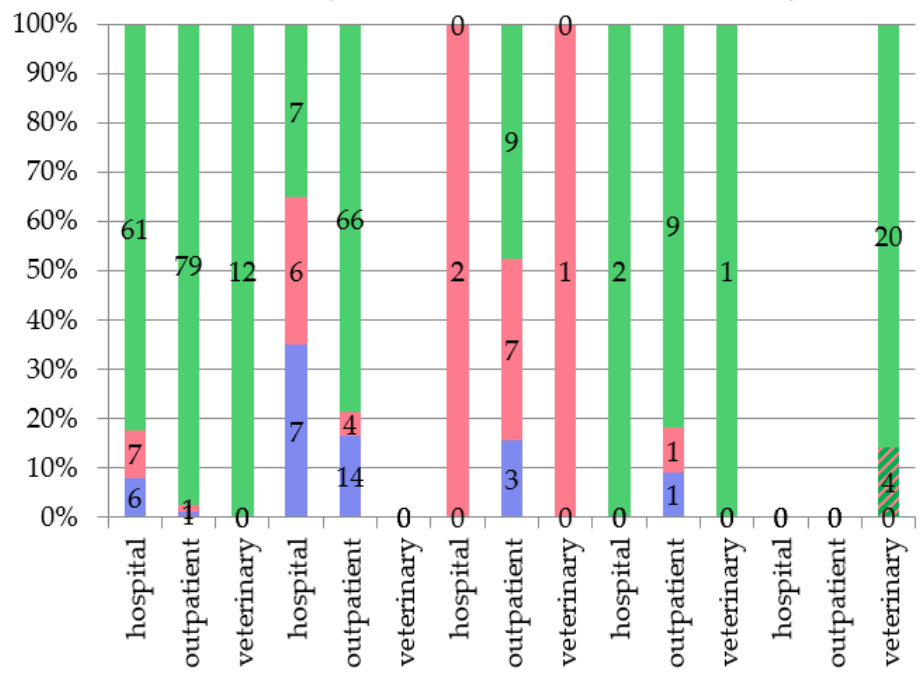

Figure 2. Resistance of predominant Staphylococcus species. MSS isolates are marked with green, MDR isolates with rose, and MRS isolates with violet. The number of corresponding isolates is shown on chart columns. ${ }^{1}$ Chart column marked with diagonal stripes correspond to four MDR S. pseudintermedius isolates sensitive to cefoxitin.

Nevertheless, MRS and MDR isolates resistant to three or more classes of antibiotics were found in all predominant species (Figure 2). All identified MDR isolates were methicillin-resistant, with the exception of S. pseudintermedius MDR isolates, which were sensitive to cefoxitin, but resistant to the tested non-beta-lactam drugs. Notably, five of seven S. aureus MDR hospital isolates were obtained from purulent diabetic ulcers and six S. epidermidis MDR hospital isolates were associated with prosthetic joint and postoperative wound infections. Isolates from the other studied Staphylococcus species $(N=63)$ were sensitive to most of the tested antibiotics; however, 10 of 63 commensal isolates were resistant to erythromycin, including all $S$. devriesei isolates, two $S$. simulans isolates, and one isolate each of M. lentus, S. borealis, S. warneri, and S. pasteuri. The S. pasteuri isolate was also resistant to gentamicin.

In addition, all isolates were assayed for antibiotic resistance genes (ARGs). The presence of the ARGs among the prevailing Staphylococcus species is shown in Table 3. The mecA gene was identified in all MRS isolates (Table 3); approximately half of all S. aureus and half of outpatient S. epidermidis isolates contained the blaZ gene, encoding penicillin resistance. The majority of aminoglycoside-resistant Staphylococcus isolates $(59 / 63)$ contained a single aac $\left(6^{\prime}\right)$-Ie-aph $\left(2^{\prime \prime}\right)$-Ia gene $(n=34)$, or its combinations with $\operatorname{aph}\left(3^{\prime}\right)$-IIIa $(n=14)$ or ant $\left(4^{\prime}\right)$-Ia $(n=11)$ genes. The erythromycin resistance of $S$. aureus isolates was encoded only by the ermA/erm C genes, not $m s r A$. In contrast, the outpatient erythromycin-resistant $S$. epidermidis isolates mostly contained $m s r A$ genes $(n=29)$. A combination of ermA and $m s r A$ was revealed in only one S. hominis isolate (Table 3). 
Table 3. Antimicrobial resistance profiles and resistance-encoding genes of prevailing Staphylococcus isolates.

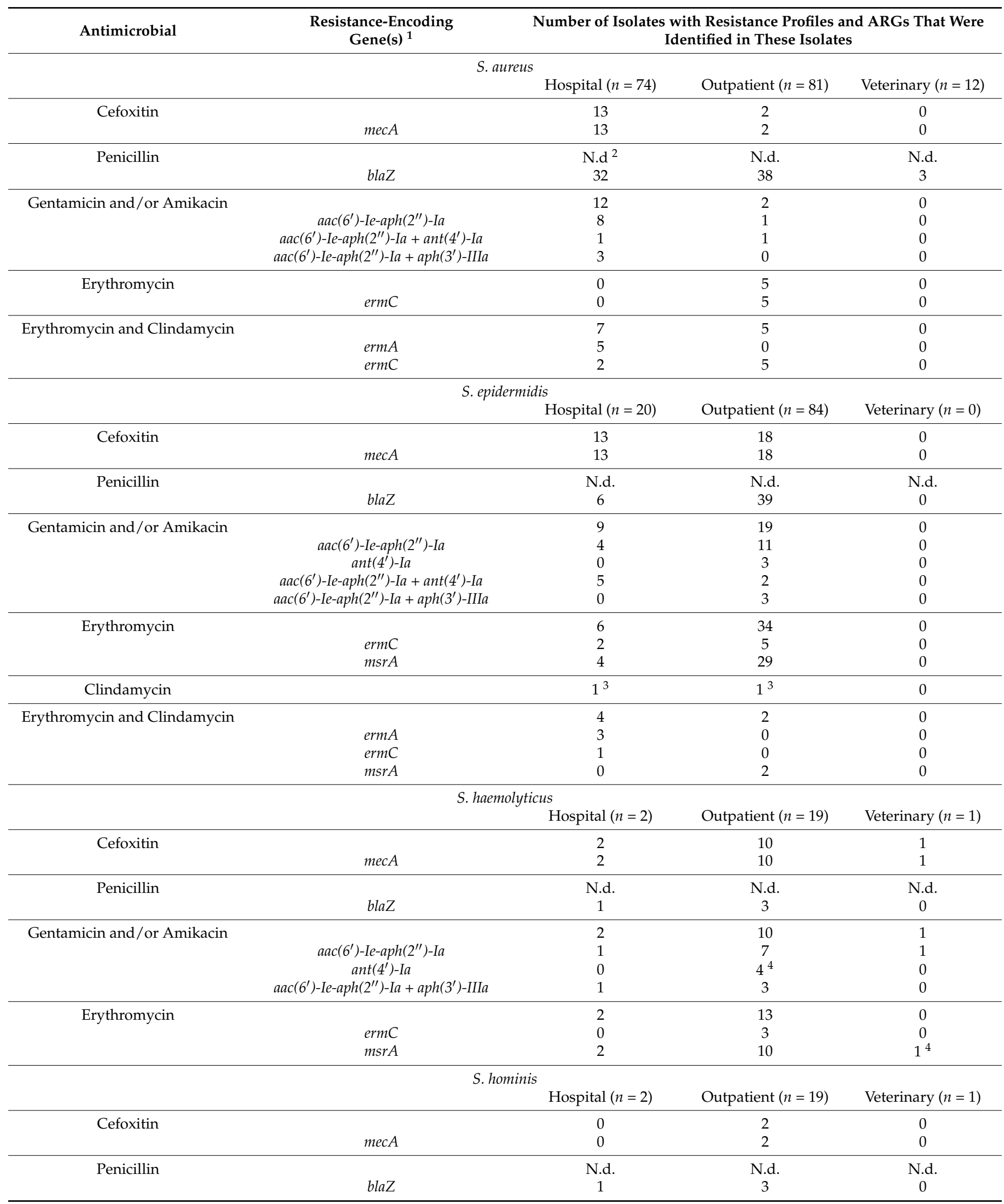


Table 3. Cont.

\begin{tabular}{|c|c|c|c|c|}
\hline Antimicrobial & $\begin{array}{l}\text { Resistance-Encoding } \\
\text { Gene(s) }{ }^{1}\end{array}$ & \multicolumn{3}{|c|}{$\begin{array}{c}\text { Number of Isolates with Resistance Profiles and ARGs That Were } \\
\text { Identified in These Isolates }\end{array}$} \\
\hline \multirow[t]{4}{*}{ Gentamicin and/or Amikacin } & & 0 & 2 & 0 \\
\hline & $\operatorname{ant}\left(4^{\prime}\right)-I a$ & 0 & $1^{4}$ & 0 \\
\hline & $\operatorname{aph}\left(3^{\prime}\right)-$-IIIa & 0 & 0 & $1^{4}$ \\
\hline & $\operatorname{aac}\left(6^{\prime}\right)-I e-a p h\left(2^{\prime \prime}\right)-I a+\operatorname{ant}\left(4^{\prime}\right)-I a$ & 0 & 2 & 0 \\
\hline \multirow{5}{*}{ Erythromycin } & & 0 & 5 & 0 \\
\hline & $m s r A$ & 0 & 4 & 0 \\
\hline & $\operatorname{erm} A+m s r A$ & 0 & 1 & 0 \\
\hline & \multicolumn{3}{|c|}{ S. pseudintermedius } & \\
\hline & & Hospital $(n=0)$ & Outpatient $(n=0)$ & Veterinary $(n=24)$ \\
\hline \multirow[t]{2}{*}{ Penicillin } & & N.d. & N.d. & N.d. \\
\hline & blaZ & 0 & 0 & 4 \\
\hline \multirow[t]{4}{*}{ Gentamicin and/or Amikacin } & & 0 & 0 & 6 \\
\hline & $a a c\left(6^{\prime}\right)-I e-a p h\left(2^{\prime \prime}\right)-I a$ & 0 & 0 & 1 \\
\hline & $\operatorname{aph}\left(3^{\prime}\right)-$ IIIa & 0 & 0 & 1 \\
\hline & $\operatorname{aac}\left(6^{\prime}\right)-\operatorname{Ie}-\operatorname{aph}\left(2^{\prime \prime}\right)-\operatorname{Ia}+\operatorname{aph}\left(3^{\prime}\right)-\mathrm{III} a$ & 0 & 0 & 4 \\
\hline \multicolumn{2}{|l|}{ Erythromycin and Clindamycin } & 0 & 0 & $7^{3}$ \\
\hline
\end{tabular}

In general, there was a clear correlation between the resistance and the presence of the corresponding ARGs. The exception was seven S. pseudintermedius erythromycinresistant isolates and two S. epidermidis clindamycin-resistant isolates; in all these isolates the $\mathrm{erm} A$, ermC, and $m s r A$ genes were not detected. Probably, other ARGs are responsible for resistance in these isolates. Conversely, genes encoding aminoglycoside resistance were determined in four S. haemolyticus and two S.hominis isolates; all of them were sensitive to aminoglycosides. The same was observed in erythromycin-sensitive strain of S. haemolyticus, in which the msrA gene was detected (Table 3). The lack of resistance in these cases is likely due to the mutant variants of the detected gene and/or the lack of its activity.

\subsection{MDR Isolate Sequence Type Identification}

Complete genomes were determined for ten and five MDR isolates of S. epidermidis and S. haemolyticus, respectively. The sequence types for staphylococcus isolates (Table 4) were determined using the PubMLST database (https: / / pubmlst.org, accessed on 15 September 2021) and the BURST analysis was used for grouping the isolates into clonal complexes [23]. Eight sequence types were found among ten $S$. epidermidis isolates; six of them were members of the CC5, one (ST23) was determined to be a member of CC23, and two ST 20 isolates were evaluated as singletons. All S. haemolyticus isolates were grouped into the clonal complex 3 (Table 4).

\subsection{Analysis of the Investigated Genomes for the Presence of Antibiotic Resistance Genes}

An ARG search was performed using Resistance Gene Identifier (https:/ / card.mcmaster. $\mathrm{ca} /$ analyze/rgi, accessed on 2 September 2021). The default selection criteria, which identified genes based on the strict or perfect mode, were used. In addition to those previously identified (Table 3), multiple ARGs have been found in the investigated genomes (Table 5). The main differences between S. epidermidis and S. haemolyticus isolates were as follows: all S. epidermidis genomes contained nor A (quinolone resistance), $\mathrm{dfrC}$ (diaminopyrimidine resistance), and fos $B$ (fosfomycin resistance), and nine of ten genomes possessed an aminocoumarin-resistant variant of gyrB. None of these genes were revealed in S. haemolyticus genomes. On the contrary, $m s r A$ and $m p h C$ (macrolide resistance) were found in all S. haemolyticus genomes but not in S. epidermidis genomes. Both the S. haemolyticus and S. epidermidis genomes had one to three different genes encoding aminoglycoside-modifying 
enzymes, and the $a a c\left(6^{\prime}\right)-I e-a p h\left(2^{\prime \prime}\right)$-Ia gene was identified in all isolates. FusC (fusidic acid resistance) and cat8 (chloramphenicol resistance) were rare and found only in S. epidermidis CEMTC 3750 and in S. haemolyticus CEMTC1553 isolates (Table 5). Genes encoding vancomycin resistance were not identified; the cluster of bacitracin resistance genes bce was found in all studied genomes.

Table 4. Source of isolation, resistance characteristics, and sequence types of MDR S. epidermidis and MDR S. haemolyticus isolates.

\begin{tabular}{|c|c|c|c|c|c|c|}
\hline No & Species & $\begin{array}{l}\text { CEMTC No of } \\
\text { Isolate/16S rRNA } \\
\text { GenBank ID }\end{array}$ & Source of Isolation & Resistance & $\begin{array}{c}\text { Sequence } \\
\text { Type }\end{array}$ & $\begin{array}{l}\text { Clonal } \\
\text { Complex }\end{array}$ \\
\hline 1 & S. epidermidis & 1827/MZ027386 & $\begin{array}{l}\text { Hospital (swab from purulent } \\
\text { diabetic ulcer) }\end{array}$ & FOX, AK, CN, E, DA & ST 23 & $\mathrm{CC} 23$ \\
\hline 2 & S. epidermidis & 1833/MZ027390 & $\begin{array}{l}\text { Hospital (pure culture, } \\
\text { post-operative wound infection) }\end{array}$ & FOX, AK, CN, E, DA & ST 23 & $\mathrm{CC} 23$ \\
\hline 3 & S. epidermidis & 2300/MZ027350 & Outpatient (nasal swab, rhinitis) & FOX, AK, CN & ST 20 & $S^{1}$ \\
\hline 4 & S. epidermidis & 3054/MZ027389 & $\begin{array}{l}\text { Hospital (pure culture, } \\
\text { post-operative wound infection) }\end{array}$ & FOX, CN, E, DA & ST 5 & CC5 \\
\hline 5 & S. epidermidis & 3107/MZ027352 & Outpatient (nasal swab, rhinitis) & FOX, CN, E & ST 152 & CC5 \\
\hline 6 & S. epidermidis & 3117/MZ027364 & Outpatient (faeces, diarrhea) & FOX, CN, E & ST 152 & CC5 \\
\hline 7 & S. epidermidis & 3750/MZ027394 & $\begin{array}{l}\text { Hospital (biopsy material, } \\
\text { prosthetic joint infection) }\end{array}$ & $\mathrm{FOX}, \mathrm{AK}, \mathrm{CN}$ & ST 210 & CC5 \\
\hline 8 & S. epidermidis & 3824/MZ027395 & $\begin{array}{l}\text { Hospital (biopsy material, } \\
\text { prosthetic joint infection) }\end{array}$ & FOX, AK, CN, E & ST 786 & CC5 \\
\hline 9 & S. epidermidis & 3918/MZ027396 & $\begin{array}{l}\text { Hospital (pure culture, } \\
\text { post-operative wound infection) }\end{array}$ & FOX, AK, CN, E & ST 20 & $S^{1}$ \\
\hline 10 & S. epidermidis & 4066/MZ027397 & $\begin{array}{l}\text { Hospital (pure culture, } \\
\text { post-operative wound infection) }\end{array}$ & FOX, AK, CN, E, DA & ST 17 & CC5 \\
\hline 11 & S. haemolyticus & 1553/MZ027371 & $\begin{array}{l}\text { Outpatient (urine } \\
\text { sample, pyelonephritis) }\end{array}$ & FOX, AK, CN, E & ST 1 & $\mathrm{CC} 3$ \\
\hline 12 & S. haemolyticus & 2119/MZ027368 & $\begin{array}{l}\text { Outpatient (purulent } \\
\text { diabetic ulcer) }\end{array}$ & FOX, CN, E & ST 3 & CC3 \\
\hline 13 & S. haemolyticus & 2688/MZ723059 & Outpatient (faeces, diarrhea) & FOX, CN, E & ST 3 & $\mathrm{CC} 3$ \\
\hline 14 & S. haemolyticus & 3413/MZ027399 & $\begin{array}{l}\text { Hospital (sputum, } \\
\text { ventilator-associated pneumonia) }\end{array}$ & FOX, AK, CN, E & ST 42 & $\mathrm{CC} 3$ \\
\hline 15 & S. haemolyticus & $3601 / \mathrm{MZ} 027370$ & $\begin{array}{l}\text { Outpatient (skin infection, } \\
\text { skin scraping) }\end{array}$ & FOX, AK, CN, E & ST 8 & CC3 \\
\hline
\end{tabular}

In addition, a number of genes encoding different MDR pumps mediating the efflux were found in the genomes. Among them, genes responsible for biocide resistance were identified, including the gene encoding acriflavin resistance protein (found in all genomes) and qacA encoding antiseptic resistance protein (identified in eight $S$. epidermidis and four S. haemolyticus genomes, except the 3107,3117 , and 2688 isolates).

\subsection{Virulence Factor Identification}

A number of VFs were identified in the investigated genomes, including genes encoding toxins, exoenzymes, and immune evasion factors (Table 6). All investigated Staphylococcus genomes contained the genes lip and nuc, encoding lipase and thermonuclease, respectively. In addition, two hemolysin-encoding genes (hemolysin III and hemolysin, containing the CBS domain) were found in all studied genomes. The $p g s A B C D E$ cluster, responsible for the synthesis of the surface-attached poly-gamma-glutamate (PGA), was also identified in all S. epidermidis and S. haemolyticus genomes (Table 6). The PGA capsule is produced by a number of coagulase-negative staphylococci and is absent in S. aureus. It is a key factor of pathogen survival during infection and efficiently shelters it from components of innate host defense, including antimicrobial peptides and neutrophil phagocytosis $[24,25]$. Only $S$. epidermidis genomes contained the gene $h l b$, encoding $\beta$-hemolysin, and a set of the genes $s s p A, s s p B$, and geh, encoding exoenzymes. 
Table 5. Antibiotic resistance genes revealed in the genomes of MDR S. epidermidis and S. haemolyticus isolates.

\begin{tabular}{|c|c|c|c|c|c|c|c|c|c|c|c|c|c|c|c|c|}
\hline \multirow[t]{2}{*}{ Antibiotic Classes } & \multirow[t]{2}{*}{ ARG } & \multicolumn{10}{|c|}{ S. epidermidis Isolates ${ }^{1}$} & \multicolumn{5}{|c|}{ S. haemolyticus Isolates 1} \\
\hline & & సે & $\underset{\infty}{\infty}$ & ஓి & ஜి & $\frac{\hat{\sigma}}{\text { ले }}$ & $\stackrel{\vec{m}}{\vec{m}}$ & 离 & $\begin{array}{l}\stackrel{N}{N} \\
\infty \\
\infty\end{array}$ & $\frac{\infty}{\sigma}$ & \&̊ & $\begin{array}{l}0 \\
\stackrel{1}{10} \\
\end{array}$ & $\stackrel{\text { ने }}{\vec{\sim}}$ & $\begin{array}{l}\infty \\
\infty \\
\infty \\
\sim\end{array}$ & $\stackrel{m}{F}$ & 客 \\
\hline Penicillins & blaZ & & $\checkmark^{2}$ & $\checkmark$ & & & $\checkmark$ & $\checkmark$ & $\checkmark$ & $\checkmark$ & $\checkmark$ & $\checkmark$ & $\checkmark$ & $\checkmark$ & $\checkmark$ & \\
\hline Cephalosporins & $\begin{array}{c}\text { mecA } \\
\text { mecI } \\
\text { mecR1 }\end{array}$ & $\begin{array}{l}\checkmark \\
\checkmark\end{array}$ & $\checkmark$ & $\begin{array}{l}\checkmark \\
\checkmark \\
\checkmark\end{array}$ & $\begin{array}{l}\checkmark \\
\checkmark\end{array}$ & $\checkmark$ & $\checkmark$ & $\checkmark$ & $\checkmark$ & $\begin{array}{l}\checkmark \\
\checkmark\end{array}$ & $\begin{array}{l}\checkmark \\
\checkmark\end{array}$ & $\checkmark$ & $\checkmark$ & $\checkmark$ & $\checkmark$ & $\checkmark$ \\
\hline $\begin{array}{l}\text { Macrolides and } \\
\text { Lincosamides }\end{array}$ & $\begin{array}{l}\text { ermA } \\
\text { ermC } \\
m s r A \\
m p h C\end{array}$ & $\checkmark$ & $\checkmark$ & & $\checkmark$ & $\checkmark$ & $\checkmark$ & $\checkmark$ & & $\checkmark$ & $\checkmark$ & $\begin{array}{l}\checkmark \\
\checkmark\end{array}$ & $\begin{array}{l}\checkmark \\
\checkmark\end{array}$ & $\begin{array}{l}\checkmark \\
\checkmark\end{array}$ & $\begin{array}{l}\checkmark \\
\checkmark\end{array}$ & $\begin{array}{l}\checkmark \\
\checkmark\end{array}$ \\
\hline Aminoglycosides & $\begin{array}{c}a \operatorname{aph}\left(3^{\prime}\right)-I I I a \\
\operatorname{ant}\left(4^{\prime}\right)-I a \\
\operatorname{aac}\left(6^{\prime}\right)-I e-a p h\left(2^{\prime \prime}\right)-I a \\
\operatorname{aad}(6) \\
\operatorname{ant}(9)\end{array}$ & $\begin{array}{l}\checkmark \\
\checkmark \\
\checkmark\end{array}$ & $\begin{array}{l}\checkmark \\
\checkmark \\
\checkmark\end{array}$ & $\begin{array}{l}\checkmark \\
\checkmark\end{array}$ & $\checkmark$ & $\checkmark$ & $\checkmark$ & $\begin{array}{l}\checkmark \\
\checkmark\end{array}$ & $\begin{array}{l}\checkmark \\
\checkmark\end{array}$ & $\begin{array}{l}\checkmark \\
\checkmark\end{array}$ & $\begin{array}{l}\checkmark \\
\checkmark\end{array}$ & $\begin{array}{l}\checkmark \\
\checkmark\end{array}$ & $\checkmark$ & $\checkmark$ & $\begin{array}{l}\checkmark \\
\checkmark\end{array}$ & $\begin{array}{l}\checkmark \\
\checkmark\end{array}$ \\
\hline Quinolones & $\begin{array}{r}\text { nor } A \\
\text { qac } A \\
\text { qac } B \\
\end{array}$ & $\begin{array}{l}\checkmark \\
\checkmark\end{array}$ & $\begin{array}{l}\checkmark \\
\checkmark \\
\end{array}$ & $\begin{array}{l}\checkmark \\
\checkmark\end{array}$ & $\begin{array}{l}\checkmark \\
\checkmark\end{array}$ & $\checkmark$ & $\checkmark$ & $\begin{array}{l}\checkmark \\
\checkmark\end{array}$ & $\begin{array}{l}\checkmark \\
\checkmark\end{array}$ & $\begin{array}{l}\checkmark \\
\checkmark\end{array}$ & $\begin{array}{l}\checkmark \\
\checkmark\end{array}$ & $\checkmark$ & $\checkmark$ & & $\checkmark$ & $\checkmark$ \\
\hline $\begin{array}{l}\text { Chlorampheni- } \\
\text { col }\end{array}$ & $\begin{array}{l}\text { cat } A 8 \\
\text { cat } A 7\end{array}$ & $\checkmark$ & $\checkmark$ & & & & & & & & & $\checkmark$ & $\checkmark$ & $\checkmark$ & $\checkmark$ & $\checkmark$ \\
\hline Fusidic acid & fusC & & & & & & & $\checkmark$ & & & & & & & & \\
\hline $\begin{array}{l}\text { Diaminopyrimi- } \\
\text { dines }\end{array}$ & $\begin{array}{l}d f r C \\
d f r G\end{array}$ & $\checkmark$ & $\checkmark$ & $\checkmark$ & $\checkmark$ & $\begin{array}{l}\checkmark \\
\checkmark\end{array}$ & $\begin{array}{l}\checkmark \\
\checkmark\end{array}$ & $\begin{array}{l}\checkmark \\
\checkmark\end{array}$ & $\checkmark$ & $\checkmark$ & $\checkmark$ & & $\checkmark$ & & $\checkmark$ & \\
\hline Aminocoumarins & $\begin{array}{l}\text { Aminocoumarin } \\
\text { resistant } g y r B\end{array}$ & $\checkmark$ & $\checkmark$ & $\checkmark$ & $\checkmark$ & $\checkmark$ & $\checkmark$ & $\checkmark$ & $\checkmark$ & & $\checkmark$ & & & & & \\
\hline Lincosamides & $\ln u A$ & & & $\checkmark$ & & & & $\checkmark$ & $\checkmark$ & $\checkmark$ & & & $\checkmark$ & $\checkmark$ & & $\checkmark$ \\
\hline Tetracyclines & $\begin{array}{l}\text { tet }(K) \\
\text { tet }(45)\end{array}$ & & & $\checkmark$ & & & & $\checkmark$ & & $\checkmark$ & & & & & & $\checkmark$ \\
\hline Fosfomycin & fos $B$ & $\checkmark$ & $\checkmark$ & $\checkmark$ & $\checkmark$ & $\checkmark$ & $\checkmark$ & $\checkmark$ & $\checkmark$ & $\checkmark$ & $\checkmark$ & & & & & \\
\hline Bacitracin & BceSR & $\checkmark$ & $\checkmark$ & $\checkmark$ & $\checkmark$ & $\checkmark$ & $\checkmark$ & $\checkmark$ & $\checkmark$ & $\checkmark$ & $\checkmark$ & $\checkmark$ & $\checkmark$ & $\checkmark$ & $\checkmark$ & $\checkmark$ \\
\hline
\end{tabular}

${ }^{1}$ S. epidermidis isolates are marked with blue, S. haemolyticus isolates are marked with green; ${ }^{2}$ the "tick" symbol means that corresponding antibiotic resistance gene was revealed in the isolate.

Table 6. Virulence factors identified in the genomes of S. epidermidis and S. haemolyticus isolates.

\begin{tabular}{|c|c|c|c|c|c|c|c|c|}
\hline \multirow[b]{2}{*}{$\begin{array}{l}\text { Species and No in } \\
\text { CEMTC }\end{array}$} & \multicolumn{4}{|c|}{ Exoenzymes } & \multicolumn{3}{|c|}{ Toxins } & \multirow{2}{*}{$\begin{array}{c}\text { Immune Evasion } \\
\text { PGA, Capsule }\end{array}$} \\
\hline & $\begin{array}{l}\text { Cysteine } \\
\text { Protease }\end{array}$ & $\begin{array}{l}\text { Serine V8 } \\
\text { Protease }\end{array}$ & Lipases & Thermonuclease & $\begin{array}{l}\text { Hemo- } \\
\text { lysin III }\end{array}$ & $\begin{array}{l}\text { Hemolysin, } \\
\text { Containing } \\
\text { CBS Domain }\end{array}$ & $\begin{array}{c}\beta- \\
\text { Hemolysin }\end{array}$ & \\
\hline S. epidermidis 1827 & $\operatorname{ssp} B$ & $\operatorname{ssp} A$ & geh, lip & nuc & +1 & $+{ }^{1}$ & $h l b$ & $c a p A, p g s A B C D E^{2}$ \\
\hline S. epidermidis 1833 & $\operatorname{ssp} B$ & $\operatorname{ssp} A$ & geh, lip & nuc & + & + & $h l b$ & capA, pgsABCDE \\
\hline S. epidermidis 2300 & $\operatorname{ssp} B$ & $\operatorname{ssp} A$ & geh, lip & nuc & + & + & $h l b$ & $\operatorname{cap} A, p g s A B C D E$ \\
\hline S. epidermidis 3054 & $s s p B$ & $\operatorname{ssp} A$ & geh, lip & nuc & + & + & $h l b$ & $\operatorname{cap} A, p g s A B C D E$ \\
\hline S. epidermidis 3107 & $\operatorname{ssp} B$ & $\operatorname{ssp} A$ & geh, lip & nuc & + & + & $h l b$ & capA, pgs $A B C D E$ \\
\hline S. epidermidis 3117 & $\operatorname{ssp} B$ & $\operatorname{ssp} A$ & geh, lip & nuc & + & + & $h l b$ & $\operatorname{capA} A, p g s A B C D E$ \\
\hline S. epidermidis 3750 & $\operatorname{ssp} B$ & $\operatorname{ssp} A$ & geh, lip & $n u c$ & + & + & $h l b$ & capA, pgsABCDE \\
\hline S. epidermidis 3824 & $\operatorname{ssp} B$ & $\operatorname{ssp} A$ & geh, lip & nuc & + & + & $h l b$ & capA, pgs $A B C D E$ \\
\hline S. epidermidis 3918 & $\operatorname{ssp} B$ & $\operatorname{ssp} A$ & geh, lip & nuc & + & + & $h l b$ & capA, pgsABCDE \\
\hline S. epidermidis 4066 & $\operatorname{ssp} B$ & $\operatorname{ssp} A$ & geh, lip & nuc & + & + & $h l b$ & capA, pgsABCDE \\
\hline S. haemolyticus 1553 & & & lip & nuc & + & + & & $\begin{array}{c}\text { capA, pgsABCDE } \\
\operatorname{cap} A, \operatorname{pgs} A B C D E, \text { cap } 5 L\end{array}$ \\
\hline S. haemolyticus 2119 & $\operatorname{ssp} B$ & $\operatorname{ssp} A$ & geh, lip & nuc & + & + & & $\begin{array}{l}\text { cap5F, cap8C, cap8E, cap } 8 I, \\
\text { cap } 8 H, \text { cap } 8 M, \text { cap } 8 N^{2}\end{array}$ \\
\hline S. haemolyticus 2688 & & & lip & nuc & + & + & & $\begin{array}{l}\text { capA, pgsABCDE, cap5A } \\
\text { capA, pgs } A B C D E, \text { cap5L }\end{array}$ \\
\hline S. haemolyticus 3413 & & & lip & nuc & + & + & & $\begin{array}{c}\text { cap5F, cap8C, cap8E, cap } 8 I, \\
\text { cap } 8 H, \text { cap } 8 M, \text { cap } 8 N^{2}\end{array}$ \\
\hline S. haemolyticus 3601 & & & lip & nuc & + & + & & $\begin{array}{c}\text { cap } A, p g s A B C D E \\
\text { cap } 5 A,{\text { cap } 8 C^{3}}^{3}\end{array}$ \\
\hline
\end{tabular}

${ }^{1}$ the "plus" symbol means that gene, encoding the appropriate hemolysin, was revealed in the isolate; ${ }^{2} p_{s} A B C D E$ cluster responsible for synthesis of the surface-attached poly-gamma-glutamate (PGA); ${ }^{3}$ putative capsule operon, possessing $\geq 50 \%$ identity to $S$. aureus cap 5 or cap8 locus. 
The number of virulence factors in the studied S. epidermidis genomes was lower compared to the known pathogenic $S$. aureus genomes. This is typical for coagulasenegative staphylococci, which are usually not as pathogenic as $S$. aureus isolates [5]. Notably, the number of VFs identified in the genomes of S. haemolyticus was lower than in the genomes of studied S. epidermidis, which may partially be due to insufficient information about the virulence factors of $S$. haemolyticus [5].

At the same time, a capsular of investigated S. haemolyticus isolates probably has a more complex structure compared to $S$. epidermidis, as additional genes encoding enzymes of capsular synthesis were revealed in the genomes of S. haemolyticus strains CEMTC 2119 and CEMTC 3413 (Table 6). These genes possess more than 50\% similarity with the closely related cap5 and cap8 gene clusters of S. aureus, which are responsible for CP5 and CP8 (the two main CP serotypes usual for clinical S. aureus strains) [26,27].

3.6. In Vitro Biofilm Formation by MDR S. epidermidis and S. haemolyticus Isolates and Factors Responsible for Adhesion and Biofilm Formation

The studied isolates have demonstrated a different ability to form biofilms (Figure 3). All isolates were divided into three categories (weak, moderate, and strong biofilm producers), as described previously [22]. Based on the cutoff value $\left(\mathrm{OD}_{\mathrm{c}}\right)$, set as three standard deviations above the mean OD of negative control and calculated as 0.15 , S. haemolyticus CEMTC 3413 was classified as a weak biofilm producer $\left(0.15<\mathrm{OD}_{\mathrm{av}} \leq 0.3\right)$, S. epidermidis CEMTC 1833, CEMTC 3750, and S. haemolyticus CEMTC 2119, CEMTC 3601 were defined as moderate biofilm producers $\left(0.3<\mathrm{OD}_{\mathrm{av}} \leq 0.6\right)$, and the remaining isolates were defined as strong biofilm producers $\left(0.6 \leq \mathrm{OD}_{\mathrm{av}}\right)$. The $S$. epidermidis CEMTC 3824 and CEMTC 3918 isolates showed the highest biofilm formation.

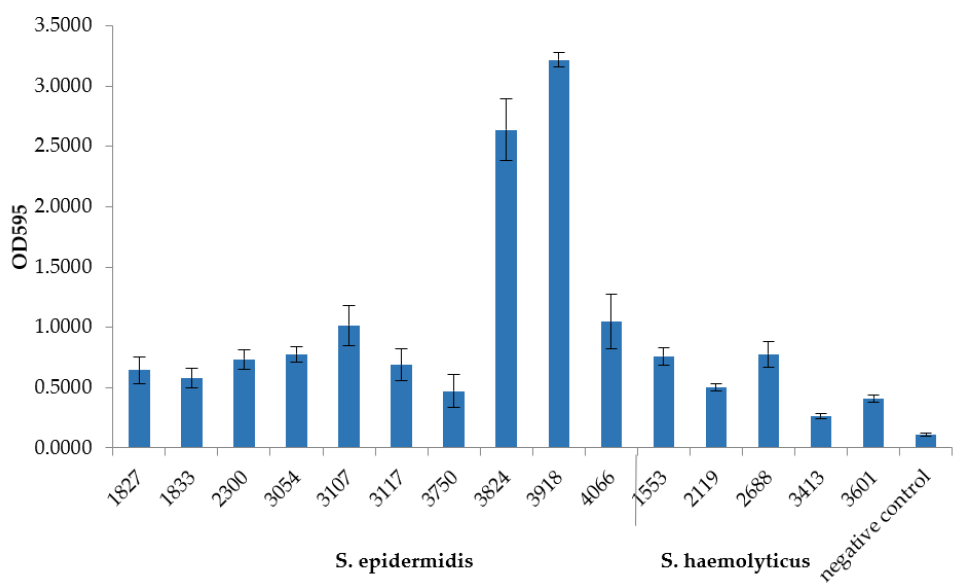

Figure 3. Biofilm formation by MDR S. epidermidis and S. haemolyticus isolates.

Two distinct mechanisms of biofilm formation have been identified previously. One involves a number of cell-wall-associated proteins (CWA), responsible for adhesion to the host cells or abiotic surfaces and subsequent biofilm production, and the other requires the synthesis and secretion of a polysaccharide intercellular adhesin (PIA) [28,29]. The genome analysis revealed a number of genes that promote biofilm formation (Table 7). All S. epidermidis and S. haemolyticus genomes contained atlE (autolysin), ebpS (elastin binding protein), and sas family genes, all of them encoding CWA proteins responsible for adhesion. A number of $s d r$ family genes, encoding Ser-Asp-rich fibrinogen-binding proteins, were found in all S. epidermidis genomes; however, two of five S. haemolyticus genomes contained a single $s d r C$ gene. The aap gene (which encodes an accumulation-associated protein, Aap) was found in the genomes of all S. epidermidis strains capable of strong biofilm production, except strain 1827. 
Table 7. Adherence and biofilm formation factors, identified in the genomes of MDR S. epidermidis and S. haemolyticus isolates.

\begin{tabular}{|c|c|c|c|c|c|c|c|c|c|c|}
\hline \multirow[b]{2}{*}{$\begin{array}{l}\text { Species and } \\
\text { No in } \\
\text { CEMTC }\end{array}$} & \multirow{2}{*}{$\begin{array}{l}\text { Ability to } \\
\text { Form } \\
\text { Biofilm }\end{array}$} & \multicolumn{9}{|c|}{ Adherence and Biofilm Formation Genes } \\
\hline & & PIA & PSM & Aap & Pls & $\begin{array}{l}\text { Sas-Family } \\
\text { Proteins }\end{array}$ & $\begin{array}{l}\text { Autoly- } \\
\sin \end{array}$ & $\begin{array}{l}\text { Fibronectin } \\
\text { Binding } \\
\text { Protein }^{1}\end{array}$ & $\begin{array}{l}\text { Elastin } \\
\text { Binding } \\
\text { Protein }\end{array}$ & $\begin{array}{c}\text { Sdr-Family } \\
\text { Proteins }\end{array}$ \\
\hline $\begin{array}{c}\text { S. epidermidis } \\
1827\end{array}$ & strong & $\begin{array}{c}i c a A D B C \\
i c a R\end{array}$ & $\begin{array}{l}p s m \beta 1, \\
p s m \beta 2\end{array}$ & & pls & SasA, SasC, SasF & atle & $e b h$ & $e b p$ & $s d r G, s d r H$ \\
\hline $\begin{array}{c}\text { S. epidermidis } \\
1833\end{array}$ & moderate & $\begin{array}{l}i c a A D B C \\
\quad i c a R\end{array}$ & & & pls & SasA, SasC, SasF & atle & $e b h$ & $e b p$ & $s d r G$ \\
\hline $\begin{array}{l}\text { S. epidermidis } \\
2300\end{array}$ & strong & $\begin{array}{l}i c a A D B C \\
i c a R\end{array}$ & $\begin{array}{l}p s m \beta 1, \\
p s m \beta 2\end{array}$ & aap & pls & SasA, SasC, SasF & atle & $e b h$ & $e b p$ & $\begin{array}{c}s d r C, s d r F \\
s d r H\end{array}$ \\
\hline $\begin{array}{l}\text { S. epidermidis } \\
3054\end{array}$ & strong & & $\begin{array}{l}p s m \beta 1, \\
p s m \beta 2\end{array}$ & aap & & SasA, SasC, SasF & atle & $e b h$ & $e b p$ & $\begin{array}{c}s d r F, s d r G \\
\quad s d r H\end{array}$ \\
\hline $\begin{array}{l}\text { S. epidermidis } \\
3107\end{array}$ & strong & & $\begin{array}{l}p s m \beta 1, \\
p s m \beta 2\end{array}$ & aap & & SasA, SasC, SasF & atle & $e b h$ & $e b p$ & $\begin{array}{l}s d r F, s d r G \\
\quad s d r H\end{array}$ \\
\hline $\begin{array}{l}\text { S. epidermidis } \\
3117\end{array}$ & strong & & $\begin{array}{l}p s m \beta 1, \\
p s m \beta 2\end{array}$ & aap & & SasA, SasC, SasF & atle & $e b h$ & $e b p$ & $\begin{array}{l}s d r F, s d r G \\
\quad s d r H\end{array}$ \\
\hline $\begin{array}{c}\text { S. epidermidis } \\
3750\end{array}$ & moderate & & $\begin{array}{l}p s m \beta 1 \\
p s m \beta 2\end{array}$ & & pls & SasA, SasC, SasF & atle & $e b h$ & $e b p$ & $\begin{array}{l}s d r E, s d r F \\
s d r G, s d r H\end{array}$ \\
\hline $\begin{array}{c}\text { S. epidermidis } \\
3824\end{array}$ & strong & $\begin{array}{l}i c a A D B C \\
\quad i_{c a R}\end{array}$ & & aap & pls & SasA, SasC, SasF & atlE & & $e b p$ & $\begin{array}{l}s d r E, s d r F \\
s d r G, s d r H\end{array}$ \\
\hline $\begin{array}{c}\text { S. epidermidis } \\
3918\end{array}$ & strong & $\begin{array}{l}i_{c a A D B C} \\
\quad i_{c a R}\end{array}$ & & aap & pls & $\begin{array}{l}\text { SasA, SasC, } \\
\text { SasF, Sas G }\end{array}$ & atle & $e b h$ & $e b p$ & $\begin{array}{l}s d r E, s d r F \\
s d r G, s d r H\end{array}$ \\
\hline $\begin{array}{c}\text { S. epidermidis } \\
4066\end{array}$ & strong & $\begin{array}{l}i c a A D B C \\
\quad i c a R\end{array}$ & $\begin{array}{l}p s m \beta 1, \\
p s m \beta 2\end{array}$ & aap & & SasA, SasC, SasF & atle & & $e b p$ & $\begin{array}{l}s d r F, s d r G \\
\quad s d r H\end{array}$ \\
\hline $\begin{array}{c}\text { S. haemolyticus } \\
1553\end{array}$ & strong & & & aap & & $\begin{array}{l}\text { SasA, SasC, } \\
\text { SasF, SasG }\end{array}$ & atle & & $e b p$ & \\
\hline $\begin{array}{c}\text { S. haemolyticus } \\
2119\end{array}$ & moderate & & & & & $\begin{array}{l}\text { SasA, SasC, } \\
\text { SasF, Sas G }\end{array}$ & atle & & $e b p$ & \\
\hline $\begin{array}{c}\text { S. haemolyticus } \\
2688\end{array}$ & strong & & & & & $\begin{array}{l}\text { SasA, SasC, } \\
\text { SasF, Sas G }\end{array}$ & atlE & & $e b p$ & \\
\hline $\begin{array}{c}\text { S. haemolyticus } \\
3413\end{array}$ & weak & & & aap & & $\begin{array}{l}\text { SasA, SasC, } \\
\text { SasF, SasG }\end{array}$ & atle & & $e b p$ & $s d r C$ \\
\hline $\begin{array}{l}\text { S. haemolyticus } \\
3601\end{array}$ & moderate & & & & & $\begin{array}{l}\text { SasA, SasC, } \\
\text { SasF, SasG }\end{array}$ & atle & & $e b p$ & $s d r C$ \\
\hline
\end{tabular}

\footnotetext{
${ }^{1}$ Extracellular matrix-binding protein (Embp) homologue [30].
}

No clear correlation between the presence of ica-operon and the ability to form biofilms was found (Table 7, Figure 3). Six S. epidermidis genomes contained ica-operon, associated with a high level of biofilm formation. Most of them, except strain 1833, were strong biofilm producers. Notably, S. epidermidis strains 3824 and 3918, which differed considerably from the others in terms of their ability to produce biofilms (Figure 3), had a combination of ica-operon, aap, pls, and four $s d r$-genes. At the same time, genes encoding phenol-soluble modulins (PSMs) were absent from both strains (Table 7). PSMs disrupt non-covalent bonds between cells inside the biofilm, promoting channel formation and cell release from the mature biofilm; mutant S. epidermidis strains, lacking PSM, were unable to form channels and produced more substantial biofilms [31-33].

In general, the investigated S. epidermidis strains were strong or moderate biofilm producers and their genomes contained multiple genes responsible for this function. At the same time, only two of five S. haemolyticus strains were capable of intense biofilm formation, and the well-known genes responsible for the formation of biofilms were poorly represented in their genomes. Presumably, their genomes contain some unidentified genes responsible for biofilm formation. Notably, both S. haemolyticus strains CEMTC 3413 and CEMTC 2119, possessing weak or moderate ability for biofilm formation, contained a putative capsule synthesis operon (Table 7). This may be one of the reasons for the weak biofilm formation-only non-encapsulated cells are able to adhere to the extracellular matrix or to endothelial cells [34]. 


\section{Discussion}

The widespread, sometimes unjustified use of antibiotics in recent decades has led to a significant increase in the proportion of antibiotic-resistant and MDR strains among nosocomial agents [35-38]. In this study, a wide spectrum of staphylococci species found in hospitalized patients and outpatients in Novosibirsk (with more than 1.5 million inhabitants) were investigated for their antibiotic resistance. In addition, staphylococci isolated from pets in close contact with humans were involved in the study, because such staphylococci can be a reservoir of pathogenic MRS and MDR strains $[39,40]$.

Only two coagulase-positive species were identified: S. aureus (in humans and pets) and S. pseudintermedius (only in pets); such staphylococci dominated in samples from hospitalized patients and pets ( $\sim 70 \%$ and $\sim 60 \%$, respectively). Seventeen coagulase-negative staphylococci were revealed, with the most variety in outpatients ( 15 species), where coagulase-negative staphylococci were in the majority $(\sim 75 \%)$. Two coagulase-negative species, S. coagulans and S. felis, were found only in veterinary samples.

Our investigation showed that the majority of isolates of all found species, with the exception of S. haemolyticus and hospital S. epidermidis isolates, were sensitive to most of the antibiotics tested and the number of MRS and MDR strains was not high. Most S. haemolyticus isolates were MRS, which corresponded to the known data on a high level of methicillin resistance in S. haemolyticus [5]. The animal isolates had the lowest antibiotic resistance to tested antibiotics, and only one veterinary S. haemolyticus MRS and four S. pseudintermedius MDR isolates (all methicillin-sensitive) were found among 61 isolates from domestic animals. Nevertheless, MRS and/or MDR isolates were found in all prevailed species, including hospital, outpatient, and veterinary isolates.

The data on MDR and MRS coagulase-negative staphylococci in different countries and regions are heterogeneous and depend on the country, region, type of hospital, etc. It is also known that hospital, community-associated, and environmental coagulase-negative isolates differ significantly in their antibiotic resistance, with the highest level of resistance a characteristic of hospital isolates. Unfortunately, the situation is changing for the worse in recent years. For instance, $17 \%$ of community-associated isolates, $30 \%$ of healthcare personnel isolates, and $\sim 87 \%$ of hospital S. epidermidis isolates were MRS in 2013 in Shanghai, China [41]. In 2018, a higher percentage of MRSE isolates (76.5\%) was recovered from healthcare personnel in two public hospitals in Tianjin, China [42]. Another study revealed that $20.5 \%$ of environmental CoNS staphylococci detected in the environment of a university in Thailand were MRS and 61.0\% of these MRS isolates were MDR [43].

The beta-lactam resistance was mediated by the mecA gene, which was found in all MRS isolates. Aminoglycoside-modifying enzymes were represented in all species and encoded mainly by the aac $\left(6^{\prime}\right)$-Ie-aph (2")-Ia gene and its combination with aph $\left(3^{\prime}\right)$-IIIa or ant $\left(4^{\prime}\right)$-Ia genes. At the same time, the macrolide resistance genes distribution was variable: only ermA/ermC genes were found in S. aureus isolates; in contrast, macrolideresistant $S$. epidermidis, S. haemolyticus, and S. hominis isolates were mostly found to contain the $m s r A$ gene. Perhaps this indicates separate ways of the resistance genes transfer between different species of coagulase-negative staphylococci. None of the macrolideresistant veterinary S. pseudintermedius isolates contained ermA/ermC or $m s r A$ genes. Other mechanisms (efflux pump or antibiotic-modifying enzymes) likely mediated macrolide resistance in these isolates.

Complete genome sequencing and analysis, which was performed for ten MDR S. epidermidis and five MDR S. haemolyticus isolates, identified other ARGs and genes associated with biofilm formation and virulence. The species-specific distribution of a number of ARGs was revealed in the genomes; nor $A, d f r C$, and fos $B$ genes were found in all S. epidermidis genomes, whereas $m p h C$ and $m s r A$ were identified in all S. haemolyticus ones.

The distribution of the macrolide-resistance-encoding genes $m s r A$ and $\operatorname{ermA} A$ erm $C$, which were found in complete genomes, was in contrast to the usual distribution of these genes among S. epidermidis isolates. Notably, almost all macrolide-resistant S. epidermidis isolates for which genome sequences were determined in this study were isolated from 
hospitalized patients; possibly, ermA/ermC genes were transmitted to S. epidermidis isolates from the nosocomial strains of $S$. aureus.

Six S. epidermidis MDR hospital isolates were associated with prosthetic joint and post-operative wound infections. The last association may be mediated by one of the major factors of S. epidermidis pathogenicity, their biofilm formation ability [5,6]. Indeed, four of the six S. epidermidis MDR hospital isolates were strong biofilm producers and the remaining two isolates demonstrated moderate biofilm-forming activity. In addition, all these strains contained the antiseptic resistance gene qacA and multiple ARGs. All of these factors were found to correlate with poor patient outcome, as was shown previously [6].

In addition, the MLST profiling revealed the genetic diversity of isolates: eight different ST were found among ten S. epidermidis isolates. The observed genetic diversity is in accordance with previously published data [44,45]. The majority of identified S. epidermidis sequence types belonged to clonal complex CC5, which has been previously reported as one of the leading causative agents for bloodstream and prosthetic joint infections [45-47]. A recent study [48] has shown that ST5 isolates can be detected as matched commensal/invasive pairings in the same human organism, unlike ST2, which is probably purely a hospital pathogen. Presumably, ST5 isolates are able to evolve in one organism from commensal to infectious variants.

A number of $S$. epidermidis isolates have been previously reported in Russia (https: //pubmlst.org, accessed on 15 September 2021). Among the sequence types identified in this study, the ST5, ST20, and ST23 isolates were found in 2008-2009 in Moscow and Nizhny Novgorod, European Russia, whereas ST786 was obtained from a hospitalized patient in 2018 in Moscow [49]. Others, namely ST17, ST152, and ST210, were found for the first time in Russia. All eight STs were revealed previously as both colonizing and infectious agents. Isolate ST210 was reported at first to be associated with samples taken from healthy people [41]; however, a number of reports of ST210 isolates causing infection were subsequently published [50,51]. The ST17, ST20, and ST23 isolates were previously identified as both colonizing and infectious agents [44]. A set of ST152 isolates were previously revealed as human-colonizing staphylococci (isolated in the USA) and as mastitis-associated agents in cows (isolated in Greece), whereas ST786 was identified in China as a community-associated isolate (https: / / pubmlst.org, accessed on 15 September 2021).

S. haemolyticus isolates were identified as belonging to four different ST; all of them were grouped into CC3. STs of S. haemolyticus isolates from Russia have not been previously reported (https: / / pubmlst.org, accessed on 15 September 2021).

In conclusion, the majority of isolates of 19 staphylococci species found in Novosibirsk in 2014-2020 were sensitive to most of the tested antibiotics. The exception was S. haemolyticus and hospital S. epidermidis isolates. Nevertheless, MRS and/or MDR isolates were found in all prevailed (S. aureus, S. epidermidis, S. haemolyticus, S. hominis, and S. pseudintermedius) species. ARGs $\left(m e c A, \operatorname{aac}\left(6^{\prime}\right)-I e-\operatorname{aph}\left(2^{\prime \prime}\right)-I a, \operatorname{aph}\left(3^{\prime}\right)-I I I a, \operatorname{ant}\left(4^{\prime}\right)-I a, \operatorname{erm} A / \operatorname{erm} C\right.$, and $\left.m s r A\right)$ were identified in staphylococcus isolates, and a clear correlation with the corresponding resistance was revealed. Complete genomes were sequenced and analyzed for ten MDR S. epidermidis and five MDR $S$. haemolyticus isolates. Antibiotic resistance genes $m p h C$, qac $A / q a c B$, nor $A, d f r C / d f r G, \operatorname{lnu} A, B s e S R$, fos $B$, and multiple genes responsible for virulence and pathogenicity were found. All investigated MDR S. epidermidis and four of five S. haemolyticus strains were moderate or strong biofilm producers, whereas multiple genes responsible for this function were identified mostly in S. epidermidis genomes and were less represented in S. haemolyticus genomes.

Supplementary Materials: The following are available online at https:/ / www.mdpi.com/article / 10.3390/microorganisms9122487/s1, Table S1: Primers, specific to antibiotic resistance encoding genes; Data S1: Staphylococcus genome sequences; Data S2: RAST annotation of the genomes. 
Author Contributions: Conceptualization, V.M. and N.T.; methodology, A.B., V.P. and N.F.; validation, S.C., A.T. and V.M.; formal analysis, A.B. and V.M.; investigation, A.B., V.F., T.K. and Y.K.; resources, V.M.; data curation, A.T., E.Z. and A.B.; writing-original draft preparation, A.B. and V.M.; writing-review and editing, N.T.; visualization, A.B. and V.M.; supervision, N.T.; project administration, V.M.; funding acquisition, V.M. All authors have read and agreed to the published version of the manuscript.

Funding: The research was funded by Russian Foundation of Basic Research and government of Novosibirsk region, project number 20-44-540012; Collection of Extremophilic Microorganisms and Type Cultures of the ICBFM SB RAS was funded with Russian State Budget Project 121031300043-8.

Institutional Review Board Statement: The study was conducted according to the guidelines of the Declaration of Helsinki, and was approved by the local Ethics Committee of the Center for New Medical Technologies in Novosibirsk; protocol \# 2, 12 February 2014.

Informed Consent Statement: Not applicable.

Data Availability Statement: The data presented in this study are available in supplementary, Data S1: Staphylococcus genome sequences; Data S2: RAST annotation of the genomes.

Acknowledgments: The authors thank Kaverina Galina for excellent technical support. Authors are grateful to Ganichev D.A. (Railway Clinical Hospital); Nimaev V.V. (Scientific Institute of Clinical and Experimental Lymphology); Yakovets E.A. (Center of New Medical Technologies); Pozdnyakova L.L. (City Infectious Diseases Clinical Hospital No. 1) for specimens obtained.

Conflicts of Interest: The authors declare no conflict of interest.

\section{References}

1. Götz, F.; Bannerman, T.; Schleifer, K.H. The Prokaryotes; Springer: New York, NY, USA, 2006; pp. 5-75.

2. Somayaji, R.; Priyantha, M.A.; Rubin, J.E.; Church, D. Human infections due to Staphylococcus pseudintermedius, an emerging zoonosis of canine origin: Report of 24 cases. Diagn. Microbiol. Infect. Dis. 2016, 85, 471-476. [CrossRef]

3. Darlow, C.A.; Paidakakos, N.; Sikander, M.; Atkins, B. A spinal infection with Staphylococcus pseudintermedius. BMJ Case Rep. 2017, 2017, bcr2017221260. [CrossRef] [PubMed]

4. Magleby, R.; Bemis, D.A.; Kim, D.; Carroll, K.C.; Castanheira, M.; Kania, S.A.; Jenkins, S.G.; Westblade, L.F. First reported human isolation of Staphylococcus delphini. Diagn. Microbiol. Infect. Dis. 2019, 94, 274-276. [CrossRef] [PubMed]

5. Argemi, X.; Hansmann, Y.; Prola, K.; Prévost, G. Coagulase-Negative Staphylococci Pathogenomics. Int. J. Mol. Sci. 2019, 20 , 1215. [CrossRef]

6. Post, V.; Harris, L.G.; Morgenstern, M.; Mageiros, L.; Hitchings, M.D.; Méric, G.; Pascoe, B.; Sheppard, S.K.; Richards, R.G.; Moriarty, T.F. A comparative genomics study of Staphylococcus epidermidis from orthopedic device-related infections correlated with patient outcome. J. Clin. Microbiol. 2017, 55, 3089-3103. [CrossRef] [PubMed]

7. Otto, M. Staphylococcus epidermidis-The 'accidental' pathogen. Nat. Rev. Microbiol. 2009, 7, 555-567. [CrossRef]

8. Namvar, A.E.; Bastarahang, S.; Abbasi, N.; Ghehi, G.S.; Farhadbakhtiarian, S.; Arezi, P.; Hosseini, M.; Baravati, S.Z.; Jokar, Z.; Chermahin, S.G. Clinical characteristics of Staphylococcus epidermidis: A systematic review. GMS Hyg. Infect. Control 2014, 9, Doc23. [CrossRef]

9. Gómez, P.; Lozano, C.; Benito, D.; Estepa, V.; Tenorio, C.; Zarazaga, M.; Torres, C. Characterization of staphylococci in urban wastewater treatment plants in Spain, with detection of methicillin resistant Staphylococcus aureus ST398. Environ. Pollut. 2016, 212, 71-76. [CrossRef]

10. Xu, Z.; Misra, R.; Jamrozy, D.; Paterson, G.K.; Cutler, R.R.; Holmes, M.A.; Gharbia, S.; Mkrtchyan, H.V. Whole genome sequence and comparative genomics analysis of multi-drug resistant environmental Staphylococcus epidermidis ST59. G3 Genes Genomes Genet. 2018, 8, 2225-2230. [CrossRef]

11. Stratchounski, L.S.; Dekhnich, A.V.; Kretchikov, V.A.; Edelstain, I.A.; Narezkina, A.D.; Afinogenov, G.E.; Akhmetova, L.I.; Boronina, L.G.; Gugutcidze, E.N.; Gudkova, L.V.; et al. Antimicrobial resistance of nosocomial strains of Staphylococcus aureus in Russia: Results of a prospective study. J. Chemother. 2005, 17, 54-60. [CrossRef]

12. Dekhnich, A.V.; Nikulin, A.A.; Ryabkova, E.L.; Krechikova, O.I.; Sukhorukova, M.V.; Kozlov, R.S.; ROSNET Study Group. Epidemiology of resistance of $S$. aureus strains isolated from patients in the ICU of Russian hospitals: Results of a multicenter study. Clin. Microbiol. Antimicrob. Chemother. 2008, 10, 333-344. (In Russian)

13. Sukhorukova, M.V.; Skleenova, E.Y.; Ivanchik, N.V.; Timokhova, A.V.; Edelstein, M.V.; Dekhnich, A.V.; Kozlov, R.S.; Shek, E.A.; «MARATHON» Study Group. Antimicrobial resistance of nosocomial Staphylococcus aureus isolates in Russia: Results of national multicenter surveillance study «MARATHON» 2011-2012. Clin. Microbiol. Antimicrob. Chemother. 2014, 16, 280-286. (In Russian)

14. Romanov, A.V.; Dekhnich, A.V.; Sukhorukova, M.V.; Skleenova, E.Y.; Ivanchik, N.V.; Edelstein, M.V.; Kozlov, R.S.; the «MARATHON» Study Group. Antimicrobial resistance of nosocomial Staphylococcus aureus isolates in Russia: Results of multicenter epidemiological study «MARATHON» 2013-2014. Clin. Microbiol. Antimicrob. Chemother. 2017, 19, 57-62. (In Russian) 
15. Barantsevich, N.E.; Barantsevich, E.P. Species diversity and methicillin resistance in Staphylococcus spp. in nosocomial infections. Clin. Microbiol. Antimicrob. Chemother. 2019, 21, 207-211. (In Russian) [CrossRef]

16. Kozlova, Y.N.; Fomenko, N.V.; Morozova, V.V.; Saranina, I.; Tikunov, A.; Ganichev, D.A.; Samokhin, A.; Pavlov, V.; Rozhnova, O.; Bondar, I.A.; et al. Genetic and biochemical characterization of staphylococci occurring in Novosibirsk, Russia. Vavilovskii Zhurnal Genet. Sel. 2017, 21, 952-958. [CrossRef]

17. Fursova, K.; Sorokin, A.; Sokolov, S.; Dzhelyadin, T.; Shulcheva, I.; Shchannikova, M.; Nikanova, D.; Artem'eva, O.; Zinovieva, N.; Brovko, F. Virulence factors and phylogeny of Staphylococcus aureus associated with bovine mastitis in Russia based on genome sequences. Front. Vet. Sci. 2020, 7, 135. [CrossRef]

18. Khokhlova, O.E.; Hung, W.C.; Wan, T.W.; Iwao, Y.; Takano, T.; Higuchi, W.; Yachenko, S.V.; Teplyakova, O.V.; Kamshilova, V.V.; Kotlovsky, Y.V.; et al. Healthcare- and community-associated methicillin-resistant Staphylococcus aureus (MRSA) and fatal pneumonia with pediatric deaths in Krasnoyarsk, Siberian Russia: Unique MRSA's multiple virulence factors, genome, and stepwise evolution. PLoS ONE 2015, 10, e0128017. [CrossRef]

19. Wan, T.W.; Khokhlova, O.E.; Iwao, Y.; Higuchi, W.; Hung, W.C.; Reva, I.V.; Singur, O.A.; Gostev, V.V.; Sidorenko, S.V.; Peryanova, O.V.; et al. Complete circular genome sequence of successful ST8/SCCmecIV community-associated methicillinresistant Staphylococcus aureus (OC8) in Russia: One-megabase genomic inversion, IS256's spread, and evolution of Russia ST8-IV. PLoS ONE 2016, 11, e0164168. [CrossRef]

20. Morozova, V.; Kozlova, Y.; Shedko, E.; Kurilshikov, A.; Babkin, I.; Tupikin, A.; Yunusova, A.; Chernonosov, A.; Baykov, I.; Kondratov, I. Lytic Bacteriophage PM16 Specific for Proteus mirabilis: A Novel Member of the genus phiKMVvirus. Arch. Virol. 2016, 161, 2457-2472. [CrossRef]

21. Madhaiyan, M.; Wirth, J.S.; Saravanan, V.S. Phylogenomic analyses of the Staphylococcaceae family suggest the reclassification of five species within the genus Staphylococcus as heterotypic synonyms, the promotion of five subspecies to novel species, the taxonomic reassignment of five Staphylococcus species to Mammaliicoccus gen. nov., and the formal assignment of Nosocomiicoccus to the family Staphylococcaceae. Int. J. Syst. Evol. Microbiol. 2020, 70, 5926-5936. [CrossRef]

22. Stepanović, S.; Vuković, D.; Hola, V.; Di Bonaventura, G.; Djukić, S.; Cirković, I.; Ruzicka, F. Quantification of biofilm in microtiter plates: Overview of testing conditions and practical recommendations for assessment of biofilm production by staphylococci. APMIS 2007, 115, 891-899. [CrossRef]

23. Jolley, K.A.; Bray, J.E.; Maiden, M.C.J. Open-access bacterial population genomics: BIGSdb software, the PubMLST.org website and their applications. Wellcome Open Res. 2018, 3, 124. [CrossRef] [PubMed]

24. Kocianova, S.; Vuong, C.; Yao, Y.; Voyich, J.M.; Fischer, E.R.; DeLeo, F.R.; Otto, M. Key role of poly-gamma-DL-glutamic acid in immune evasion and virulence of Staphylococcus epidermidis. J. Clin. Investig. 2005, 115, 688-694. [CrossRef] [PubMed]

25. Takeuchi, F.; Watanabe, S.; Baba, T.; Yuzawa, H.; Ito, T.; Morimoto, Y.; Kuroda, M.; Cui, L.; Takahashi, M.; Ankai, A.; et al. Whole-genome sequencing of Staphylococcus haemolyticus uncovers the extreme plasticity of its genome and the evolution of human-colonizing staphylococcal species. J. Bacteriol. 2005, 187, 7292-7308. [CrossRef] [PubMed]

26. Flahaut, S.; Vinogradov, E.; Kelley, K.A.; Brennan, S.; Hiramatsu, K.; Lee, J.C. Structural and biological characterization of a capsular polysaccharide produced by Staphylococcus haemolyticus. J. Bacteriol. 2008, 190, 1649-1657. [CrossRef] [PubMed]

27. Keinhörster, D.; Salzer, A.; Duque-Jaramillo, A.; George, S.E.; Marincola, G.; Lee, J.C.; Weidenmaier, C.; Wolz, C. Revisiting the regulation of the capsular polysaccharide biosynthesis gene cluster in Staphylococcus aureus. Mol. Microbiol. 2019, 112, 1083-1099. [CrossRef]

28. Arciola, C.R.; Campoccia, D.; Ravaioli, S.; Montanaro, L. Polysaccharide intercellular adhesin in biofilm: Structural and regulatory aspects. Front. Cell. Infect. Microbiol. 2015, 5, 7. [CrossRef]

29. Foster, T.J. Surface Proteins of Staphylococcus epidermidis. Front. Microbiol. 2020, 11, 1829. [CrossRef]

30. Clarke, S.R.; Harris, L.G.; Richards, R.G.; Foster, S.J. Analysis of Ebh, a 1.1-megadalton cell wall-associated fibronectin-binding protein of Staphylococcus aureus. Infect. Immun. 2002, 70, 6680-6687. [CrossRef]

31. Wang, R.; Khan, B.A.; Cheung, G.Y.; Bach, T.H.; Jameson-Lee, M.; Kong, K.F.; Queck, S.Y.; Otto, M. Staphylococcus epidermidis surfactant peptides promote biofilm maturation and dissemination of biofilm-associated infection in mice. J. Clin. Investig. 2011, 121, 238-248. [CrossRef]

32. Dastgheyb, S.S.; Villaruz, A.E.; Le, K.Y.; Tan, V.Y.; Duong, A.C.; Chatterjee, S.S.; Cheung, G.Y.C.; Joo, H.-S.; Hickok, N.J.; Otto, M. Role of phenol-soluble modulins in formation of Staphylococcus aureus biofilms in synovial fluid. Infect. Immun. 2015, 83, $2966-2975$. [CrossRef] [PubMed]

33. Le, K.Y.; Park, M.D.; Otto, M. Immune evasion mechanisms of Staphylococcus epidermidis biofilm infection. Front. Microbiol. 2018, 9, 359. [CrossRef] [PubMed]

34. Pöhlmann-Dietze, P.; Ulrich, M.; Kiser, K.B.; Döring, G.; Lee, J.C.; Fournier, J.M.; Botzenhart, K.; Wolz, C. Adherence of Staphylococcus aureus to endothelial cells: Influence of capsular polysaccharide, global regulator agr, and bacterial growth phase. Infect. Immun. 2000, 68, 4865-4871. [CrossRef] [PubMed]

35. Santajit, S.; Indrawattana, N. Mechanisms of antimicrobial resistance in ESKAPE pathogens. BioMed Res. Int. 2016, $2016,2475067$. [CrossRef] [PubMed]

36. Suwantarat, N.; Carroll, K.C. Epidemiology and molecular characterization of multidrug-resistant Gram-negative bacteria in Southeast Asia. Antimicrob. Resist. Infect. Control 2016, 5, 15. [CrossRef] 
37. Pedroso, S.; Sandes, S.; Filho, R.; Nunes, A.C.; Serufo, J.C.; Farias, L.M.; Carvalho, M.; Bomfim, M.; Santos, S.G. Coagulasenegative staphylococci isolated from human bloodstream infections showed multidrug resistance profile. Microb. Drug Resist. 2018, 24, 635-647. [CrossRef]

38. Asante, J.; Amoako, D.G.; Abia, A.; Somboro, A.M.; Govinden, U.; Bester, L.A.; Essack, S.Y. Review of clinically and epidemiologically relevant coagulase-negative staphylococci in Africa. Microbial. Drug Resist. 2020, 26, 951-970. [CrossRef]

39. Ben Zakour, N.L.; Beatson, S.A.; van den Broek, A.H.; Thoday, K.L.; Fitzgerald, J.R. Comparative genomics of the Staphylococcus intermedius group of animal pathogens. Front. Cell. Infect. Microbiol. 2012, 2, 44. [CrossRef]

40. Jantorn, P.; Heemmamad, H.; Soimala, T.; Indoung, S.; Saising, J.; Chokpaisarn, J.; Wanna, W.; Tipmanee, V.; Saeloh, D. Antibiotic Resistance Profile and Biofilm Production of Staphylococcus pseudintermedius Isolated from Dogs in Thailand. Pharmaceuticals 2021, 14, 592. [CrossRef] [PubMed]

41. Du, X.; Zhu, Y.; Song, Y.; Li, T.; Luo, T.; Sun, G.; Yang, C.; Cao, C.; Lu, Y.; Li, M. Molecular analysis of Staphylococcus epidermidis strains isolated from community and hospital environments in China. PLoS ONE 2013, 8, e62742. [CrossRef] [PubMed]

42. Xu, Z.; Cave, R.; Chen, L.; Yangkyi, T.; Liu, Y.; Li, K.; Meng, G.; Niu, K.; Zhang, W.; Tang, N.; et al. Antibiotic resistance and molecular characteristics of methicillin-resistant Staphylococcus epidermidis recovered from hospital personnel in China. J. Glob. Antimicrob. Resist. 2020, 22, 195-201. [CrossRef] [PubMed]

43. Seng, R.; Leungtongkam, U.; Thummeepak, R.; Chatdumrong, W.; Sitthisak, S. High prevalence of methicillin-resistant coagulasenegative staphylococci isolated from a university environment in Thailand. Int. Microbiol. 2017, 20, 65-73. [CrossRef] [PubMed]

44. Miragaia, M.; Thomas, J.C.; Couto, I.; Enright, M.C.; de Lencastre, H. Inferring a population structure for Staphylococcus epidermidis from multilocus sequence typing data. J. Bacteriol. 2007, 189, 2540-2552. [CrossRef]

45. Mendes, R.E.; Deshpande, L.M.; Costello, A.J.; Farrell, D.J. Molecular epidemiology of Staphylococcus epidermidis clinical isolates from U.S. hospitals. Antimicrob. Agents Chemother. 2012, 56, 4656-4661. [CrossRef] [PubMed]

46. Deplano, A.; Vandendriessche, S.; Nonhoff, C.; Dodemont, M.; Roisin, S.; Denis, O. National surveillance of Staphylococcus epidermidis recovered from bloodstream infections in Belgian hospitals. J. Antimicrob. Chemother. 2016, 71, 1815-1819. [CrossRef]

47. Cremniter, J.; Sivadon-Tardy, V.; Caulliez, C.; Bauer, T.; Porcher, R.; Lortat-Jacob, A.; Piriou, P.; Judet, T.; Aegerter, P.; Herrmann, J.-L.; et al. Genetic analysis of glycopeptide-resistant Staphylococcus epidermidis strains from bone and joint infections. J. Clin. Microbiol. 2013, 51, 1014-1019. [CrossRef]

48. Both, A.; Huang, J.; Qi, M.; Lausmann, C.; Weißelberg, S.; Büttner, H.; Lezius, S.; AFailla, V.; Christner, M.; Stegger, M.; et al. Distinct clonal lineages and within-host diversification shape invasive Staphylococcus epidermidis populations. PLoS Pathog. 2021, 17, e1009304. [CrossRef]

49. Skachkova, T.S.; Zamyatin, M.N.; Orlova, O.A.; Yumtsunova, N.A.; Lashenkova, N.N.; Fomina, V.S.; Gusarov, V.G.; Mikhaylova, Y.V.; Shelenkov, A.A.; Goloveshkina, E.N.; et al. Monitoring methicillin-resistant staphylococcus strains in the Moscow medical and surgical center using molecular-biological methods. Epidemiol. Vaccinal Prev. 2021, 20, 44-50. [CrossRef]

50. Lee, J.Y.H.; Monk, I.R.; Gonçalves da Silva, A.; Seemann, T.; Chua, K.Y.L.; Kearns, A.; Hill, R.; Woodford, N.; Bartels, M.D.; Strommenger, B.; et al. Global spread of three multidrug-resistant lineages of Staphylococcus epidermidis. Nat. Microbiol. 2018, 3, 1175-1185. [CrossRef]

51. Arora, S.; Li, X.; Hillhouse, A.; Konganti, K.; Little, S.V.; Lawhon, S.D.; Threadgill, D.; Shelburne, S.; Hook, M. Staphylococcus epidermidis MSCRAMM SesJ is encoded in composite islands. mBio 2020, 11, e02911-19. [CrossRef] 